\title{
Comparison of Two Different Blood Sample Tubes for Platelet Function Analysis with the Multiplate ${ }^{\circledast}$ System
}

\author{
Ralph M. Loreth Gudrun Klose \\ Klinische Hämostaseologie, Medizinische Klinik III, Westpfalz-Klinikum GmbH, Kaiserslautern, Germany
}

\section{Keywords \\ Platelet function analysis - Blood sample tubes . Whole blood aggregometry}

\section{Summary}

Background: For whole blood aggregation on the Multiplate ${ }^{\circledR}$ system, the use of thrombin inhibitor as anticoagulant is recommended. So far sample tubes containing liquid lepirudin were provided (Dynabyte, Munich, Germany). They are not sterile and have to be stored refrigerated. For better handling now also sterile tubes with dried hirudin, storable at room temperature, are also provided (Dynabyte). The aim of this study was to compare the performance of these both sample tubes on the Multiplate system. Patients and Methods: Blood was collected from 30 patients, treated with aspirin and/or clopidogrel, in tubes, and ASPItest, ADPtest and TRAPtest were performed. Results: The correlation between both sample tubes was excellent with ASPItest $\left(r^{2}=0.96\right)$, good with ADPtest $\left(r^{2}=0.91\right)$ and also satisfying with TRAPtest $\left(r^{2}=0.85\right)$. Conclusion: Both sample tubes are well qualified for platelet function analysis with the Multiplate system. The new sterile sample tube with dried hirudin may be preferred for better handling.

\author{
Schlüsselwörter \\ Thrombozytenfunktionsdiagnostik . \\ Blutabnahmeröhrchen · Vollblutaggregation
}

\section{Zusammenfassung}

Einleitung: Für die Vollblutaggregation am Multiplate ${ }^{\circledR}$ System wird die Verwendung von Thrombininhibitoren als Antikoagulanz empfohlen. Bisher wurden hierzu Blutentnahmeröhrchen mit flüssigem Lepirudin zur Verfügung gestellt (Dynabyte, München, Deutschland). Diese sind nicht steril und müssen bei $2-8{ }^{\circ} \mathrm{C}$ gelagert werden. Zur besseren Handhabung werden nun auch sterile Blutentnahmeröhrchen mit getrocknetem Hirudin angeboten, welche bei Raumtemperatur lagerbar sind (Dynabyte). Ziel dieser Studie war der Vergleich beider Blutentnahmeröhrchen am Multiplate-System. Patienten und Methoden: Bei 30 Patienten, welche mit Aspirin und/ oder Clopidogrel behandelt worden waren, wurde Blut in beide Blutentnahmeröhrchen abgenommen und der ASPItest, der ADPtest sowie der TRAPtest durchgeführt. Ergebnisse: Die Korrelation zwischen beiden Blutentnahmeröhrchen war sehr gut im ASPItest $\left(r^{2}=0,96\right)$, gut im ADPtest $\left(r^{2}=0,91\right)$ und ebenfalls zufriedenstellend im TRAPtest $\left(r^{2}=0,85\right)$. Schlussfolgerungen: Beide Blutentnahmeröhrchen eignen sich sehr gut für die Thrombozytenfunktionsdiagnostik am Multiplate-System. Aufgrund der besseren Handhabung ist dabei das neue sterile Blutentnahmeröhrchen mit getrocknetem Hirudin zu bevorzugen.

\begin{tabular}{ll}
\hline KARGER & @ 2010 S. Karger GmbH, Freiburg \\
Fax +497614520714 & Accessible online at: \\
Information@Karger.de & www.karger.com/tmh \\
www.karger.com &
\end{tabular}




\section{Introduction}

For coagulation tests blood is usually anticoagulated with sodium citrate as a standard anticoagulant. This results in nonphysiologically low calcium concentration in the sample and limits the use for platelet function assays, as calcium is an important second messenger in platelet activation [1]. So one effect of citrate-induced reduction of ionized calcium is the enhancement of platelet responses to ADP [2], leading to different reaction of platelets in citrated blood than in the circulation. Furthermore, platelets rapidly loss there viability in citrated blood samples, and the time between blood collection and testing have to be kept in a narrow rage [3,4]. With the introduction of the Multiplate ${ }^{\circledR}$ system for multiple electrode platelet aggregometry (MEA) in whole blood the use of thrombin inhibitor as anticoagulant was highly recommended
Fig. 1. Correlation between liquid lepirudin tubes $(\mathrm{Ti})$ and dried lepirudin tubes (Hi) with ASPItest; $\mathrm{r}^{2}=$ coefficient of determination.
Fig. 2. Correlation between liquid lepirudin tubes $(\mathrm{Ti})$ and dried lepirudin tubes (Hi) with ADPtest; $\mathrm{r}^{2}=$ coefficient of determination.
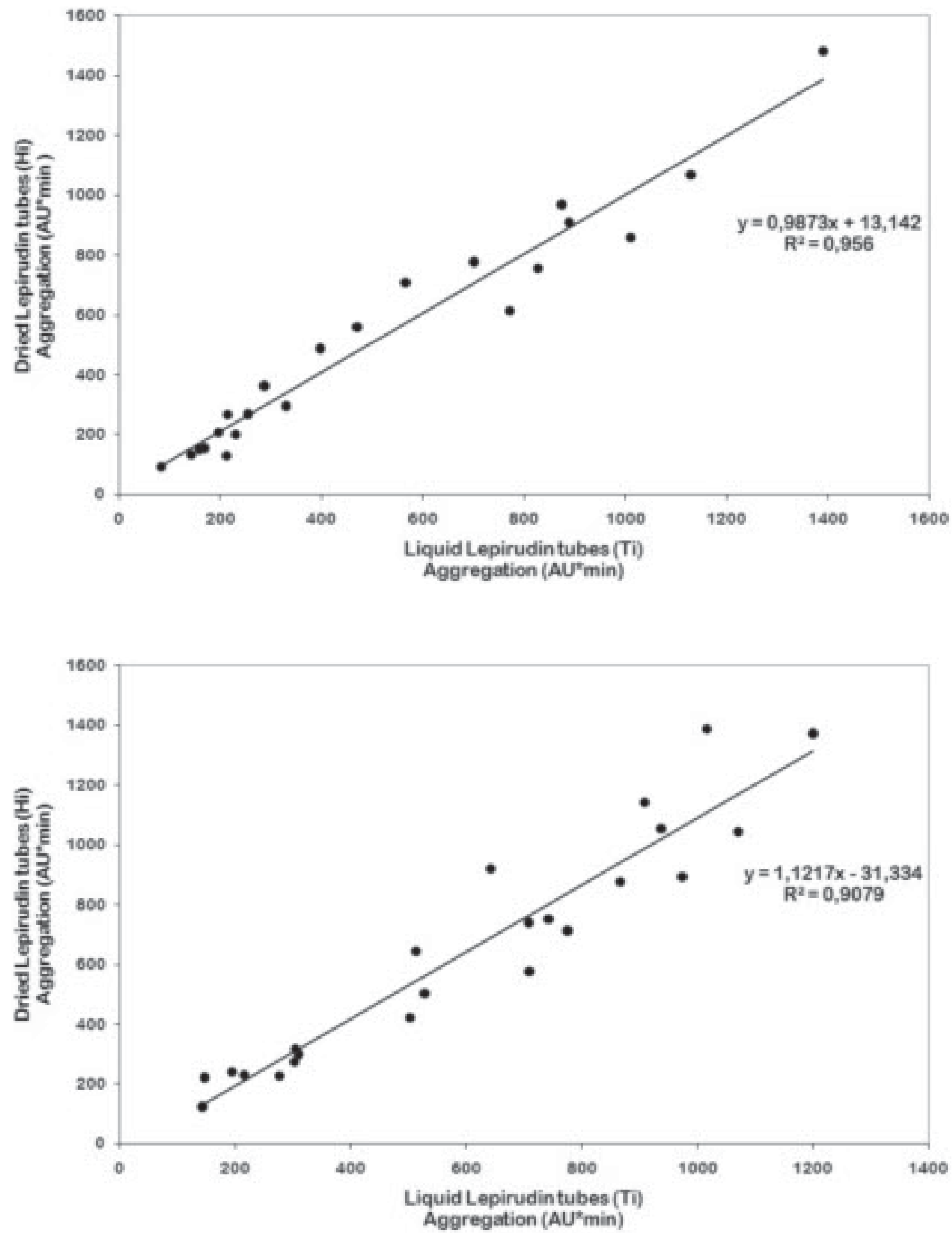
Fig. 3. Correlation between liquid lepirudin tubes $(\mathrm{Ti})$ and dried lepirudin tubes (Hi) with TRAPtest; $r^{2}=$ coefficient of determination.
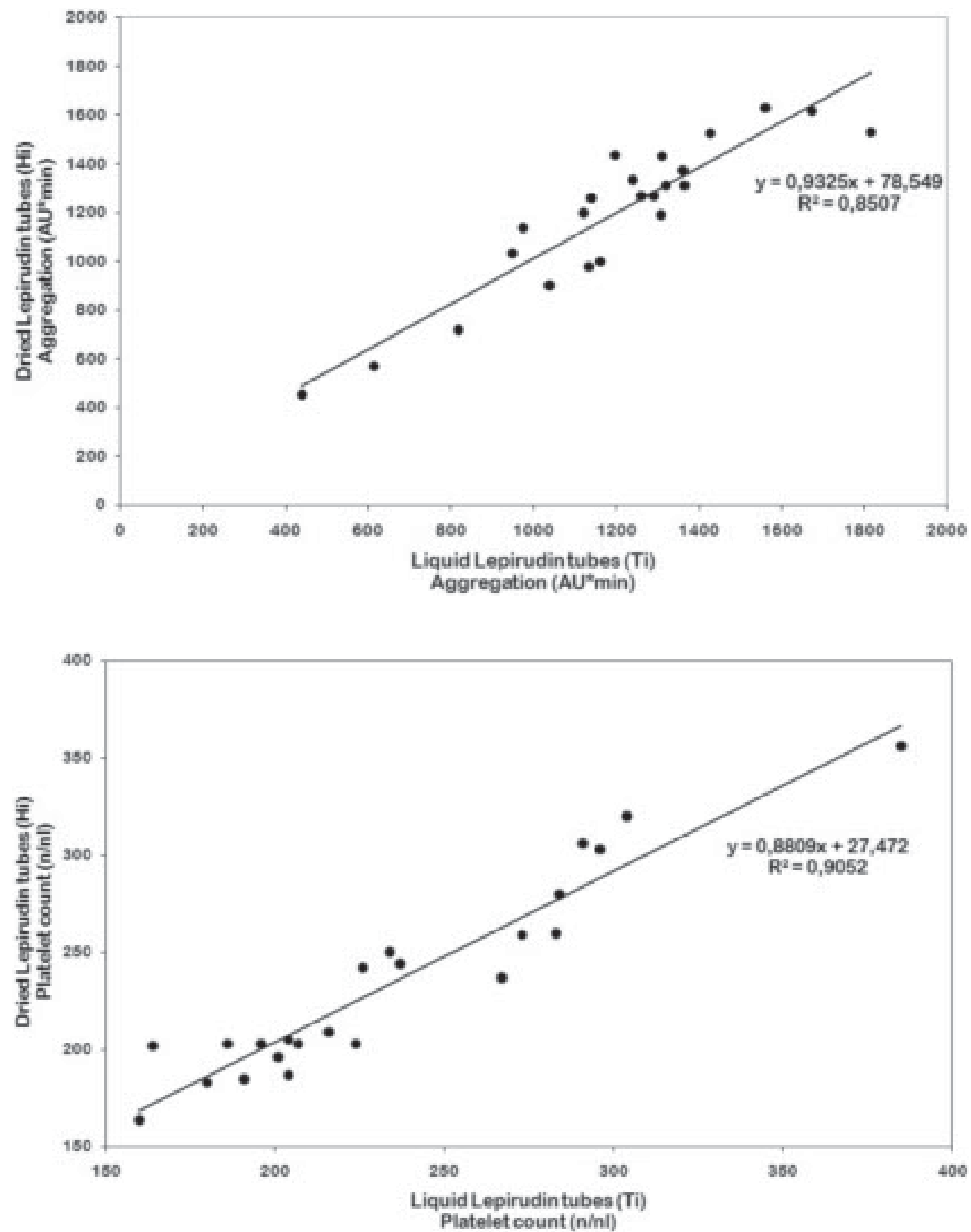

Fig. 4. Correlation of platelet count between liquid lepirudin tubes $(\mathrm{Ti})$ and dried lepirudin tubes (Hi); $\mathrm{r}^{2}=$ coefficient of determination. by the manufacturer (Dynabyte, Munich, Germany) [5]. Therefore, the manufacturer provides sample tubes containing liquid lepirudin in a final concentration of $25 \mu \mathrm{g} / \mathrm{ml}$. As they are not sterile, they have a short storage time and have to be kept refrigerated at $2-8{ }^{\circ} \mathrm{C}$. This handling is unfavorable in clinical practice. For an easier use now also sterile sample tubes with dried lepirudin are provided by the manufacturer. The aim of this study was to compare the performance of both sample tubes on the Multiplate system in routine clinical praxis.

\section{Patients and Methods}

30 outpatients (11 females and 19 males, aged between 22 and 86 years, median 61 years) referred to our ward for examination of antiplatelet therapy gave informed consent and were included in this study. 11 of them were treated with aspirin, 6 with clopidogrel and 13 with both. After a 15 -min rest in a sitting position, blood samples were drawn with light tourniquets and short and moderate phlebostasis from the antecubital vein using 19-gauge butterfly needles. The first $3 \mathrm{ml}$ were collected into S-Monovettes ${ }^{\circledR}$ (Sarstedt, Nuembrecht, Germany) containing potassium 
EDTA and were used for blood cell counts. For analysis at the Multiplate system, blood was drawn into non-sterile 5-ml S-Monovettes containing liquid lepirudin ( $\mathrm{Ti}$ ) in a final concentration of $25 \mu \mathrm{g} / \mathrm{ml}$ and into sterile 5-ml S-Monovettes containing spray dried lepirudin (Hi), also in a final concentration of $25 \mu \mathrm{g} / \mathrm{ml}$. Both S-Monovettes are assembled and provided by Dynabyte.

After a 30-min rest MEA was performed at the Multiplate system as recommended by the manufacturer, adding $0.3 \mathrm{ml}$ preheated $\left(37^{\circ} \mathrm{C}\right)$ isotonic saline to $0.3 \mathrm{ml}$ whole blood in the Multiplate test cell, followed by incubation for $3 \mathrm{~min}$ at $37^{\circ} \mathrm{C}$. Then aggregation was induced by adding arachidonic acid (ASPItest), ADP (ADPtest) or TRAP-6 (TRAPtest). The aggregation response over 6 min was expressed by the area under the curve as arbitrary units $(\mathrm{AU} \times \mathrm{min})$. Statistical comparison between both sample tubes was performed by linear regression analysis using Microsoft Excel 2007 (Redmond, WS, USA).

The trial protocol has been approved by a local ethical committee and meets the standards of the Declaration of Helsinki in its revised version of 1975 and its amendments of 1983,1989 and 1996.

\section{Results}

Figures 1-3 show the correlation between both blood sample tubes with the ASPItest, the ADPtest and the TRAPtest. The coefficient of determination was 0.96 with the ASPItest, 0.91 with the ADPtest and 0.5 with the TRAPtest. Aggregation results expressed as $\mathrm{AU} \times$ min were only by trend slightly higher in the Hi sample tubes with the TRAPtest. Platelet count did not significant differ between both test tubes (fig. 4).

\section{Discussion}

Previous studies have established direct thrombin inhibitors such as lepirudin as anticoagulants for platelet function studies because these inhibitors, in contrast to citrate, keep up physiological levels of calcium ions and have no direct effect on platelets $[4,6-8]$. In both sample tubes of this comparative study, lepirudin was used - in a liquid form in one tube and in a spray dried form in the other. Our results show no significant differences in aggregation results between both sample tubes. There was an even excellent correlation between both sample tubes with the ASPItest, also a good correlation with the ADPtest and still satisfying correlation with the TRAPtest. Platelet counts did not significantly differ between both sample tubes.

In conclusion, blood samples with both tubes are well qualified for aggregation on the Multiplate system. The new sterile sample tube with dried lepirudin may be preferred for better handling. Each laboratory, using the new sample tubes should establish its own reference ranges.

\section{Disclosure}

The authors declared no conflict of interest.

\section{References}

1 Lages B, Weiss HJ: Dependence of human platelet functional responses on divalent cations: aggregation and secretion in heparin- and hirudin-anticoagulated platelet-rich plasma and the effects of chelating agents. Thromb Haemost 1981;45:173-179.

2 Heptinstall S, Taylor PM: The effects of citrate and extracellular calcium ions on the platelet release reaction induced by adenosine diphosphate and collagen. Thromb Haemost 1979;42:778-793.

3 Harrison P: Platelet function analysis. Blood Rev 2005;19:111-123.
4 May JA, Heptinstall S: Effects of anticoagulants used during blood collection on human platelet function. Methods Mol Biol 2004;272:3-11.

5 Calatzis A, Wittwer M, Krueger B: A new approach to platelet function analysis in whole blood - the Multiplate Analyzer. Platelets 2004;15;484-486.

6 Tóth O, Calatzis A, Penz S, Losonczy H, Siess W: Multiple electrode aggregometry: a new device to measure platelet aggregation in whole blood. Thromb Haemost 2006;96:781-788.
7 Glusa E, Markwardt F: Platelet functions in recombinant hirudin-anticoagulated blood. Haemostasis 1990;20:112-118.

8 Blecher PR, Muriithi EW, Day SP, Wheatley DJ: Platelet aggregatory response to low-dose collagen are maintained in hirudin-anticoagulated whole blood for $25 \mathrm{~h}$ when stored at room temperature. Platelets 2001;12:34-36. 